\title{
Endothelin-1 induces changes in the expression levels of steroidogenic enzymes and increases androgen receptor and testosterone production in the $\mathrm{PC} 3$ prostate cancer cell line
}

\author{
MARÍA JOSÉ TORRES ${ }^{1}$, FERNANDA LÓPEZ-MONCADA ${ }^{2}$, DANIELA HERRERA ${ }^{1}$, \\ SEBASTIÁN INDO ${ }^{3}$, ALEJANDRO LEFIAN ${ }^{1}$, PAOLA LLANOS $^{4}$, JULIO TAPIA ${ }^{5}$, \\ ENRIQUE A. CASTELLÓN ${ }^{1}$ and HÉCTOR R. CONTRERAS ${ }^{1}$
}

\author{
${ }^{1}$ Department of Basic and Clinical Oncology, Faculty of Medicine, University of Chile, Santiago 8380453; \\ ${ }^{2}$ Laboratory of Endocrinology and Reproductive Biology, University of Chile Clinical Hospital, \\ Faculty of Medicine, University of Chile, Santiago 8380000 ; ${ }^{3}$ Department of Medical Technology, \\ Faculty of Medicine, University of Chile, Santiago 8380453; ${ }^{4}$ Institute for Research in Dental Sciences, \\ Faculty of Dentistry, University of Chile, Santiago 8380544; ${ }^{5}$ Institute of Biomedical Sciences, \\ Faculty of Medicine, University of Chile, Santiago 8380453, Chile
}

Received October 31, 2020; Accepted May 5, 2021

DOI: $10.3892 /$ or.2021.8122

\begin{abstract}
Endothelin-1 (ET-1) is involved in the regulation of steroidogenesis. Additionally, patients with castration-resistant prostate cancer (PCa) have a higher ET-1 plasma concentration than those with localized PCa and healthy individuals. The aim of the present study was to evaluate the effect of ET-1 on steroidogenesis enzymes, androgen receptor (AR) and testosterone (T) production in PCa cells. The expression levels of endothelin receptors in prostate tissue from patients with localized PCa by immunohistochemistry, and those in LNCaP and $\mathrm{PC} 3$ cells were determined reverse transcription-quantitative PCR (RT-qPCR) and western blotting. Furthermore, the expression levels of ET-1 were determined in LNCaP and PC 3 cells by RT-qPCR and western blotting. The ET-1 receptor activation was evaluated by intracellular calcium measurement, the expression levels of AR and enzymes participating in steroidogenesis [cytochrome P450 family 11 subfamily A member 1 (CyP11A1), cytochrome P450 family 17 subfamily A member 1, aldo-keto reductase family member $\mathrm{C} 2$ and $3 \beta$-hydroxysteroid dehydrogenase/isomerase 2 (3 $\beta$ HSD2)] were determined by western blotting and $\mathrm{T}$ concentration was determined by ELISA using PC 3 cells.
\end{abstract}

Correspondence to: Dr Héctor R. Contreras or Dr Enrique A.Castellón, Department of Basic and Clinical Oncology, Faculty of Medicine, University of Chile, Independencia 1027, Block H, Santiago 8380453, Chile

E-mail: hcontrer@med.uchile.cl

E-mail: ecastell@med.uchile.cl

Key words: castration-resistant prostate cancer, endothelin-1, endothelin receptor, steroidogenesis, androgen receptor
The present results revealed higher expression levels of endothelin $\mathrm{A}$ receptor $\left(\mathrm{ET}_{\mathrm{A}} \mathrm{R}\right)$ in tissues obtained from samples of patients with PCa with a low Gleason Score. No changes were identified for endothelin $B$ receptor $\left(E_{B} R\right)$. PC3 cells expressed higher levels of ET-1 and $\mathrm{ET}_{\mathrm{A}} \mathrm{R}$, while $\mathrm{LNCaP}$ cells exhibited higher expression levels of $E_{B} R$. Blocking of $E_{A} R$ and endothelin $\mathrm{B}$ receptor decreased the expression levels of CyP11A1 and $3 \beta$ HSD2 enzymes and AR in PC 3 cells, as well as $\mathrm{T}$ secretion. These findings suggested that ET-1 has a potential role in modulating the intratumoral steroidogenesis pathway and might have relevance as a possible therapeutic target.

\section{Introduction}

Prostate cancer (PCa) is the fifth most common cause of cancer-associated mortality among men worldwide (1). Digital rectal examination and determination of prostate-specific antigen levels within the blood are techniques that are commonly used to screen for PCa (2). If these techniques suggest the presence of $\mathrm{PCa}$, the diagnosis is confirmed using a transrectal biopsy analysis $(2,3)$. Current treatments for clinically localized or advanced PCa include radical prostatectomy, cryoablation, radiation therapy, brachytherapy and androgen deprivation therapy (ADT) $(2,4)$.

The androgens [testosterone $(\mathrm{T})$ and dihydrotestosterone] are hormones, which are required for the development of the reproductive system and male secondary sex characteristics $(4,5)$. These hormones exert their physiological actions via interaction with the androgen receptor (AR), which is a ligand-dependent transcriptional factor belonging to the superfamily of nuclear receptors (5). Androgens serve an important role in the development and growth of a normal prostate gland and in the proliferation of PCa cells $(6,7)$. Therefore, ADT is often used as a first line treatment to control advanced PCa (8). 
However, after 2-3 years of treatment, PCa develops resistance to ADT, resulting in castration-resistant PCa (CRPC) (8). Hypersensitivity, mutations, splicing variants or amplification of the AR and intratumoral steroidogenesis have been indicated to be mechanisms that may lead to androgen resistance (6). Steroidogenesis begins with the translocation of cholesterol to the inner membrane of the mitochondria via steroidogenic acute regulatory protein (9). In addition, cytochrome P450 family 11 subfamily A member 1 (CyP11A1), cytochrome P450 family 17 subfamily A member 1 (CyP17A 1$), 3 \beta$ hydroxysteroid dehydrogenase type 2 (3 $\beta$ HSD2), 17 $\beta$-hydroxysteroid dehydrogenase type 3 and $5 \alpha$ reductase type 1 and 2 are the main enzymes that are required to complete androgen de novo synthesis from cholesterol (9).

A number of previous studies have demonstrated that steroidogenic cells expressing endothelin receptor increase steroidogenesis when stimulated with endothelin-1 (ET-1) (10-12). Furthermore, patients with metastatic CRPC have been reported to exhibit increased ET-1 plasma levels compared with patients with localized PCa and healthy individuals (13-17), suggesting that ET-1 may contribute to the transition from androgen-dependent PCa to CRPC. ET-1, which is a potent vasoconstrictor peptide containing 21 amino acid residues, is associated with a number of aspects of $\mathrm{PCa}$ progression, including proliferation, escape from apoptosis, invasion, angiogenesis and new bone formation $(16,18,19)$.

Leydig cells have been indicated to express high levels of endothelin receptors (12) and increase basal $\mathrm{T}$ secretion when stimulated with ET-1 $(10,11)$. Additionally, endothelin receptor $A\left(E T_{A} R\right)$ activation by $E T-1$ has been revealed to increase AR mRNA expression via c-myc in androgenindependent LNCaP cells, contributing to androgenic independence (20). However, to the best of our knowledge, the role of endothelin receptors in non-steroidogenic cells, including PCa cells, has not yet been described. In the present study, an ET-1-dependent increase in the expression levels of steroidogenic enzymes and an increase in AR and T production in PCa cells were observed.

\section{Materials and methods}

Chemicals and materials. ET-1 was purchased from Sigma-Aldrich; Merck KGaA. ET-1 receptor antagonists, 2-[(3R,6R,9S,12R,15S)-6-(1H-indol-3-ylmethyl)-9-(2-methylp ropyl)-2,5,8,11,14-pentaoxo-12-propan-2-yl-1,4,7,10,13-pentazabicyclo[13.3.0]octadecan-3-yl] acetic acid or cyclo(D-tryptamine-D-aspartic acid-L-proline-D-valine-L-leucine) (BQ123) and 2,6-Dimethylpiperidinecarbonyl- $\gamma$-Methyl-Leu-N $\mathrm{N}_{\text {in }}$ (Methoxycarbonyl)-D-Trp-D-Nle,-N-[N-[N-[(2,6-Dimethyl-1-piperidinyl) carbonyl]-4-methyl-L-leucyl]-1-(methoxycarbonyl)-D-tryptophyl]-D-norleucine sodium salt (BQ788) were purchased from Cayman Chemical Company and bosentan was purchased from Sigma-Aldrich; Merck KGaA. The salts, chloroform and alcohols were obtained from MilliporeSigma and Hank's buffer was obtained from Thermo Fisher Scientific, Inc.

Endothelin receptor and AR blockade. Cells were incubated with $\mathrm{BQ} 123\left(\mathrm{ET}_{\mathrm{A}} \mathrm{R}\right.$ selective antagonist; $\left.1 \mu \mathrm{M}\right), \mathrm{BQ788}$ [endothelin $\mathrm{B}$ receptor $\left(\mathrm{ET}_{\mathrm{B}} \mathrm{R}\right)$ selective antagonist; $1 \mu \mathrm{M}$ ] or bosentan $\left(\mathrm{ET}_{\mathrm{A}} \mathrm{R}\right.$ and $\mathrm{ET}_{\mathrm{B}} \mathrm{R}$ dual antagonist; $\left.1 \mu \mathrm{M}\right)$ for $30 \mathrm{~min}$ at $37^{\circ} \mathrm{C}$ with $5 \% \mathrm{CO}_{2}$. In all experiments, DMSO $0.1 \%$ was used.

Cell culture. PCa cells from androgen-dependent lymph nodal metastases ( $\mathrm{LNCaP}$ ) and PCa cells from bone metastases (PC3) were obtained from American Type Culture Collection. LNCaP cells, clone FDG (CRL1740), were maintained in RPMI-1640 medium (Gibco; Thermo Fisher Scientific, Inc.) and PC3 cells (CRL1435) were maintained in DMEM F12 medium (Gibco; Thermo Fisher Scientific, Inc.). Both media were supplemented with $10 \%$ FBS (Thermo Fisher Scientific, Inc.), $1 \%$ penicillin, $1 \%$ streptomycin and $0.05 \%$ amphotericin B (Corning, Inc.). All cell cultures were maintained at $37^{\circ} \mathrm{C}$ in a humidified atmosphere with $5 \% \mathrm{CO}_{2}$. The media of PC3 cells were replaced with phenol red-free RPMI (Gibco; Thermo Fisher Scientific, Inc.) supplemented with $10 \%$ activated charcoal (Sigma-Aldrich; Merck KGaA)-treated FBS, $1 \%$ streptomycin, $0.05 \%$ amphotericin $\mathrm{B}$ and $1 \%$ penicillin $24 \mathrm{~h}$ before the different treatments. Afterwards, cells were washed with PBS three times and harvested.

Tissue microarrays (TMAs). A TMA was constructed with $5-\mu \mathrm{m}$ sections of formalin $(10 \% \mathrm{v} / \mathrm{v})$-fixed for $24 \mathrm{~h}$ at room temperature and paraffin-embedded PCa samples from male patients (age range, 47-80 years; mean age, 63.7 years) with different Gleason Score (GS) (21) from the biopsy archive of our institutional Pathology Department (Clinical Hospital of the University of Chile, Santiago, Chile). All samples were diagnosis biopsies collected in different years (March 2016-January 2018) with a confirmed diagnosis and GS. The sample inclusion criterion was: PCa confirmed. All protocols for tissue archive use and processing have been approved by the institutional Ethical Committee of Faculty of Medicine, University of Chile (approval nos. 135-2015 and 083-2020). For diagnosis biopsies, patients were asked to sign a general consent when biopsies were obtained. For the use of the archive of biopsies from the Pathology Service, a signed authorization of the director of the Department of Pathology, University of Chile (authorization 03012016; Santiago, Chile) is required. TMAs with cores of $1 \mathrm{~mm}$ in diameter, including 7 samples with a low GS $(\mathrm{GS}<7), 14$ samples with an intermediate GS $(\mathrm{GS}=7)$ and 11 samples with a high GS $(\mathrm{GS}>7)$ were obtained and evaluated by a pathologist.

Immunohistochemistry. TMA tissue sections were deparaffinized and rehydrated in decreasing concentrations of ethanol and distilled water [xylene (x2), ethanol 100\% (x2), ethanol $95 \%$, ethanol $70 \%$ and distilled water], and incubated for $40 \mathrm{~min}$ at $95^{\circ} \mathrm{C}$ in antigen recovery buffer $(10 \mathrm{mM}$ citrate buffer, pH 6.0). After cooling, endogenous peroxidase was inhibited by incubation with $0.3 \% \mathrm{H}_{2} \mathrm{O}_{2}$ for $30 \mathrm{~min}$ and samples were blocked with $2.5 \%$ horse serum (Vector Laboratories, Inc.) for $30 \mathrm{~min}$ at room temperature. Then, sections were incubated with primary antibody against $\mathrm{ET}_{\mathrm{A}} \mathrm{R}$ (dilution, 1:300; cat. no. PA3-065; Thermo Fisher Scientific, Inc.) or $\mathrm{ET}_{\mathrm{B}} \mathrm{R}$ (dilution, 1:800; cat. no. PA3-066; Thermo Fisher Scientific, Inc.) overnight at $4^{\circ} \mathrm{C}$. Subsequently, the samples were washed and incubated with secondary antibody conjugated to the HRP enzyme for $1 \mathrm{~h}$ at room temperature (ready to use; anti-rabbit-mouse-IgG; cat. no. PK-7200; Vector Laboratories, 
Table I. Reverse transcription-quantitative PCR oligonucleotides.

\begin{tabular}{lll}
\hline Gene & \multicolumn{1}{c}{ Forward (5'-3') } & \multicolumn{1}{c}{ Reverse $\left(5^{\prime}-3^{\prime}\right)$} \\
\hline $\mathrm{ET}_{\mathrm{A}} \mathrm{R}$ & GAACATCTTAAGCAGCGTCGAG & ACCGATGTAATCCATGAGCAGT \\
$\mathrm{ET}_{\mathrm{B}} \mathrm{R}$ & GCTTGCTTCATCCCGTTCAGA & CTTCCCGTCTCTGCTTTAGGTG \\
$\mathrm{ET}-1$ & CAGGGCTGAAGACATTATGGAGA & CATGGTCTCCGACCTGGTTT \\
Pumilio & CGGTCGTCCTGAGGATAAAA & CGTACGTGAGGCGTGAGTAA \\
\hline
\end{tabular}

$\mathrm{ET}_{\mathrm{A}} \mathrm{R}$, endothelin A receptor; $\mathrm{ET}_{\mathrm{B}} \mathrm{R}$, endothelin B receptor; ET-1, endothelin-1.

Inc.). Then, samples were washed and incubated with $\mathrm{ABC}$ amplification system for $30 \mathrm{~min}$ at room temperature (ready to use; cat. no. PK-7 200; Vector Laboratories, Inc.). Finally, the chromogenic substrate 3,3'-diaminobenzidine (DAB) was added. Furthermore, the nuclei were stained with hematoxylin (ScyTek Laboratories, Inc.) for $1 \mathrm{~min}$ at room temperature. Images were obtained using a Leica DM2500 light microscope (Leica Microsystems $\mathrm{GmbH}$ ), digitized and the DAB signal was quantified by ImageJ $1.51 \mathrm{w}$ software (National Institutes of Health), using the IHC toolbox plugin (https://imagej.nih. gov/ij/plugins/ihc-toolbox/index.html) and plotted using GraphPad Prism version 7.1 (GraphPad Software, Inc.). For semi-quantitative analysis of immunohistochemistry results, the gray level transformation method was implemented, using the logarithmic transformation technique. The digitized images were processed through gray level transformation techniques, since it operates directly on the pixels. The image involves 256 levels of gray, so in the histogram on the horizontal axis it ranges from 0 to 255 levels of gray. On the other hand, the vertical axis differs from the number of pixels in the image. The Log (255/average color/grays in the selected area) was determined as previously described (22).

RNA extraction and quantification. Total RNA was isolated from cells using TRIzol ${ }^{\circledR}$ (Thermo Fisher Scientific, Inc.), chloroform, isopropanol and $75 \%$ ethanol. Subsequently, nuclease free water (diethylpyrocarbonate-treated) was used to re-suspend extracted RNA. The purity and concentration of RNA were determined by spectrophotometry at 260/280 nm using a BioTeK Synergy HT plate reader (BioTek Instruments, Inc.).

Reverse transcription-quantitative PCR (RT-qPCR). A total of 1,000 ng total RNA from each sample was used for cDNA synthesis using the $5 \mathrm{X}$ All-In-One RT MasterMix kit $\left(25^{\circ} \mathrm{C}\right.$ for $10 \mathrm{~min}, 42^{\circ} \mathrm{C}$ for $15 \mathrm{~min}$ and $85^{\circ} \mathrm{C}$ for $5 \mathrm{~min}, 1$ cycle; Applied Biological Materials Inc.). Subsequently, $50 \mathrm{ng} / \mathrm{ml}$ were amplified by qPCR using the Brilliant II SYBR Green qPCR Master Mix kit $\left(95^{\circ} \mathrm{C}\right.$ for $10 \mathrm{~min}, 1$ cycle; $95^{\circ} \mathrm{C}$ for $15 \mathrm{~min}, 60^{\circ} \mathrm{C}$ for $15 \mathrm{~min}$ and $72^{\circ} \mathrm{C}$ for $15 \mathrm{~min}, 40$ cycles; $95^{\circ} \mathrm{C}$ for $15 \mathrm{~min}, 65^{\circ} \mathrm{C}$ for $15 \mathrm{~min}$ and $95^{\circ} \mathrm{C}$ for $15 \mathrm{~min}, 1$ cycle; Agilent Technologies, Inc.). RT-qPCR oligonucleotides are shown in Table I. The housekeeping gene Pumilio was used to normalize data and the results were analyzed using the $\Delta \Delta \mathrm{Cq}$ method (23). To facilitate comparison, data were referred to those cells that express the highest levels of the receptor. PC3 cells expressed the highest levels of $\mathrm{ET}_{\mathrm{A}} \mathrm{R}$ mRNA and protein, so the expression levels of $\mathrm{ET}_{\mathrm{A}} \mathrm{R}$ of $\mathrm{LNCaP}$ cells were compared with PC3 cells. By contrast, LNCaP cells expressed the highest levels of $\mathrm{ET}_{\mathrm{B}} \mathrm{R}$ mRNA and protein, so $\mathrm{ET}_{\mathrm{B}} \mathrm{R}$ expression levels of PC3 cells were compared with LNCaP cells.

Intracellular calcium measurement. PC3 cells were grown on 25-mm diameter glass coverslips and kept in DMEM F12 medium for $24 \mathrm{~h}$. Subsequently, the cells were washed with PBS and loaded with $2 \mu \mathrm{M}$ Fluor-4 acetoxymethyl ester (Fluo4/AM; Thermo Fisher Scientific, Inc.) at room temperature for $15 \mathrm{~min}$. Subsequently, the cells were maintained in Hank's Balanced Salt Solution at a final volume of $500 \mu \mathrm{l}$ containing $142 \mathrm{mM} \mathrm{NaCl}, 5.6 \mathrm{mM} \mathrm{KCl}, 1 \mathrm{mM}$ $\mathrm{MgCl}_{2}, 2 \mathrm{mM} \mathrm{CaCl}_{2}, 0.34 \mathrm{mM} \mathrm{Na}_{2} \mathrm{HPO}_{4}, 0.44 \mathrm{mM} \mathrm{KH}_{2} \mathrm{PO}_{4}$, $4.2 \mathrm{mM} \mathrm{NaHCO}, 10 \mathrm{mM}$ HEPES and $5.6 \mathrm{mM}$ glucose. On the one hand, $100 \mathrm{nM}$ ET-1 was added at $60 \mathrm{sec}$ after reaction was initiated with Fluo4/AM, at room temperature, to cells previously incubated with DMSO or with selective antagonists for endothelin receptors, at $37^{\circ} \mathrm{C}$ for $30 \mathrm{~min}$. In all experiments DMSO (0.1\%) was used. On the other hand, $17 \mathrm{mM}$ carbachol (positive control) was added at $245 \mathrm{sec}$ after reaction was initiated with Fluo4AM, at room temperature, to cells preincubated with $\mathrm{BQ} 123$ at $37^{\circ} \mathrm{C}$ for $30 \mathrm{~min}$. The kinetics recording was carried out for $300 \mathrm{sec}$ and the fluorescence intensity was measured in an AxioCam MRm (Carl Zeiss AG) coupled to a Carl Zeiss AG inverted fluorescence microscope AxioVert.A1 equipped for epifluorescence and the Image J 1.51w software (National Institutes of Health) was used.

Indirect immunofluorescence. PC3 and LNCaP cells were grown on $12-\mathrm{mm}$ diameter glass coverslips seeded at a confluence of $60-70 \%$. After $24-48 \mathrm{~h}$, the cells were fixed with a fixing solution (4\% paraformaldehyde) for $30 \mathrm{~min}$ at room temperature, washed and blocked with $3 \%$ BSA (Winkler, Ltd.) in PBS-glycine for $30 \mathrm{~min}$ at room temperature. Cells were incubated overnight at $4{ }^{\circ} \mathrm{C}$ with the primary antibodies against $\mathrm{ET}_{\mathrm{A}} \mathrm{R}$ (dilution, 1:200; cat. no. PA3-065; Thermo Fisher Scientific, Inc.) and $\mathrm{ET}_{\mathrm{B}} \mathrm{R}$ (dilution, 1:200; cat. no. PA3-066; Thermo Fisher Scientific, Inc.), washed and incubated for $30 \mathrm{~min}$ at $37^{\circ} \mathrm{C}$ with the secondary antibody Alexa Fluor 594 (dilution, 1:500; cat. no. A21207; Thermo Fisher Scientific, Inc.). DAPI (dilution, 1:10,000; cat. no. sc3598; Santa Cruz Biotechnology, Inc.) was used for nuclear staining for $7 \mathrm{~min}$ at room temperature. The images were obtained using a Leica D2500 fluorescence microscope (Leica Microsystems GmbH). 
Table II. Primary antibodies for western blotting.

\begin{tabular}{lllr}
\hline Primary antibody & \multicolumn{1}{c}{ Supplier } & Cat. no. & \multicolumn{1}{c}{ Species } \\
\hline ET $_{\mathrm{A}} \mathrm{C}$ & Thermo Fisher Scientific, Inc. & PA3-065 & \multicolumn{1}{c}{ Rabbit anti-human } \\
ET $_{\mathrm{B}} \mathrm{R}$ & Thermo Fisher Scientific, Inc. & PA3-066 & Rabbit anti-human \\
ET-1 & Santa Cruz Biotechnology, Inc. & sc-517436 & Mouse anti-human \\
CyP11A1 & Abcam & ab- 75497 & Rabbit anti-human \\
CyP17A1 & Merck KGaA. & ABC392 & Rabbit anti-human \\
AKR1C2 & Thermo Fisher Scientific, Inc. & PA5-36572 & Rabbit anti-human \\
$3 \beta$ HSD2 & Thermo Fisher Scientific, Inc. & PA5-27791 & Rabbit anti-human \\
AR & Abcam & ab- 9474 & Mouse anti-human \\
Actin & MP Biomedicals, LLC & 691002 & $1: 500$ \\
& & & Mouse anti-human
\end{tabular}

$\mathrm{ET}_{\mathrm{A}} \mathrm{R}$, endothelin A receptor; $\mathrm{ET}_{\mathrm{B}} \mathrm{R}$, endothelin B receptor; ET-1, endothelin-1; CyP11A1, cytochrome P450 family 11 subfamily A member 1;

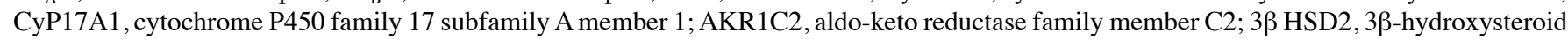
dehydrogenase/isomerase 2; AR, androgen receptor.

Table III. Secondary antibodies.

\begin{tabular}{llr}
\hline Secondary antibody & Supplier & Cat. no. \\
\hline Anti-rabbit & Jackson ImmunoResearch Laboratories, Inc. & $111-035-003$ \\
Anti-mouse & Jackson ImmunoResearch Laboratories, Inc. & $115-035-003$ \\
\hline
\end{tabular}

Western blotting. Proteins obtained from cell lines were extracted using RIPA buffer $(20 \mathrm{mM}$ Tris- $\mathrm{HCl}, 150 \mathrm{mM}$ $\mathrm{NaCl}, 1 \mathrm{mM}$ EDTA, $1 \% \mathrm{v} / \mathrm{v}$ NP-40, $1 \% \mathrm{w} / \mathrm{v}$ sodium deoxycholate, $2.5 \mathrm{mM} \mathrm{Na} \mathrm{PO}_{4}, 1 \mathrm{mM}$ b-glycerophosphate and $1 \mathrm{mM} \mathrm{Na} \mathrm{VO}_{4}, \mathrm{pH}$ 7.4) with a protease inhibitor cocktail (Roche Diagnostics). The homogenate was centrifuged at $16,708 \mathrm{x} \mathrm{g}$ for $15 \mathrm{~min}$ at $4^{\circ} \mathrm{C}$. Finally, the supernatant was quantified using a Bradford assay. A total of $25 \mu \mathrm{g}$ of protein was loaded per lane, separated by SDS-PAGE (10 or $12 \%$ polyacrylamide for $\mathrm{ET}_{\mathrm{A}} \mathrm{R}$ and $\mathrm{ET}_{\mathrm{B}} \mathrm{R}$ ), and transferred to a nitrocellulose membrane, except for detection of $3 \beta$ HSD2, for which protein was transferred to a PVDF membrane. The membranes were blocked at room temperature with 5\% BSA (Winkler, Ltd.) or milk of $0.2 \%$ TBS-Tween for $90 \mathrm{~min}$ and exposed to the primary antibody overnight at $4^{\circ} \mathrm{C}$. After washing, the binding of the primary antibodies was detected with secondary antibodies conjugated with the HRP enzyme for $90 \mathrm{~min}$ at room temperature, and detected using EZ-ECL chemiluminescence kit (Biological Industries) and a Vilber Lourmat equipment (Fusion FX5-XT 826.WL/superbright serial number 15200393; Vilber). Primary and secondary antibodies for western blotting are shown in Tables II and III, respectively. The densitometric analysis of western blot bands was performed using ImageJ v1.51 software (National Institutes of Health).

Determination of T levels in cell culture medium. PC3 cells were grown on 6-well plates in RPMI medium free of phenol red with $10 \%$ androgen-free FBS. After $24 \mathrm{~h}$, DMSO (control) or endothelin receptor antagonist was added for $30 \mathrm{~min}$ at $37^{\circ} \mathrm{C}$, and then $100 \mathrm{nM}$ ET-1 was added every $24 \mathrm{~h}$ at $37^{\circ} \mathrm{C}$.
In all experiments, DMSO (0.1\%) was used. After $96 \mathrm{~h}$, the culture medium was removed and centrifuged at $1,000 \mathrm{x} \mathrm{g}$ for $5 \mathrm{~min}$ at room temperature. The number of viable cells was quantified in each condition. Parameter Testosterone Assay (cat. no. KGE010; R\&D Systems, Inc.) was used for T determination in culture supernatant according to the manufacturer's protocols. The assay was based on a competitive binding technique. A total of $50 \mu \mathrm{l}$ of a monoclonal antibody specific for $\mathrm{T}$ (excluding non-specific binding wells) was added for binding the anti-mouse antibody coated microplate and incubated with shaking for $1 \mathrm{~h}$ at room temperature. After three washes with wash buffer $(400 \mu \mathrm{l}), 100 \mu \mathrm{l}$ calibrator (non-specific binding wells and B0, zero standard), $100 \mu \mathrm{l}$ standard, control or sample (remaining wells) were added. Subsequently, $50 \mu 1$ conjugated $\mathrm{T}$ was incorporated into each well, and incubated for $3 \mathrm{~h}$ at room temperature on a horizontal orbital microplate shaker at $37 \mathrm{x} \mathrm{g}$ After three washes with wash buffer, $200 \mu \mathrm{l}$ of the substrate were added for $30 \mathrm{~min}$ at room temperature. Afterwards, $50 \mu \mathrm{l}$ of the stop solution was added to stop the reaction. Finally, the optical density was determined within $30 \mathrm{~min}$ by spectrophotometry at $450 \mathrm{~nm}$ using the BioTeK Synergy HT plate reader (BioTek Instruments, Inc.).

Statistical analysis. Plots were obtained using the GraphPad Prism 7.1 software (GraphPad Software, Inc.). Data are presented as the mean $\pm \mathrm{SD}$ of at least three independent experiments for RT-qPCR and western blotting. Mann Whitney or Kruskal-Wallis (Dunn's multiple comparisons test) test was carried out. The box plots represent the signal intensity of $\mathrm{ET}_{\mathrm{A}} \mathrm{R}$ and $\mathrm{ET}_{\mathrm{B}} \mathrm{R}$ in each group. The points outside the box represent the outliers. The number of samples 
A

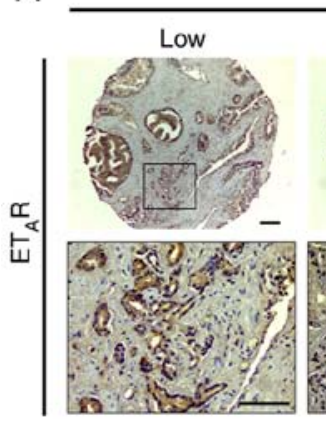

Gleason score

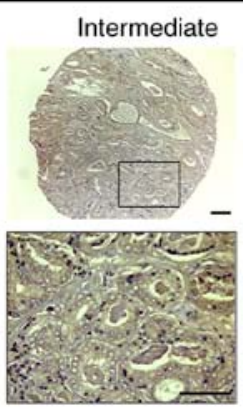

Gleason score

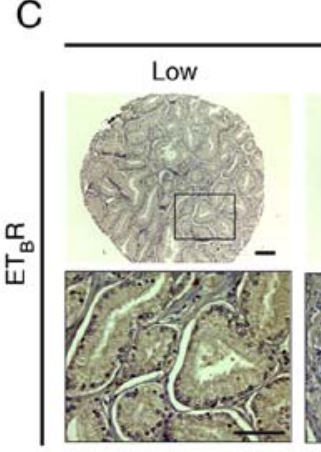

Intermediate

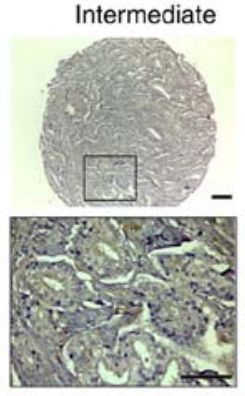

Negative control
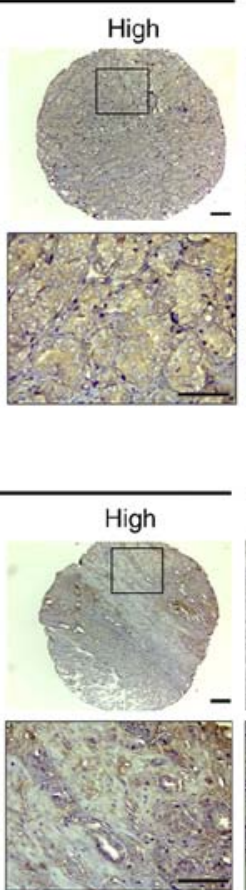

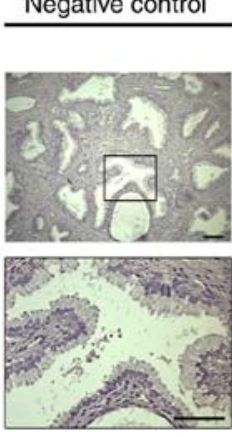

Negative control

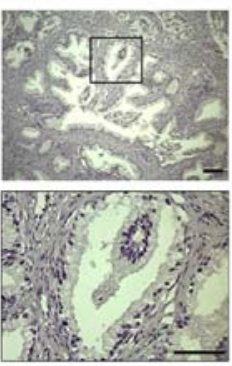

B

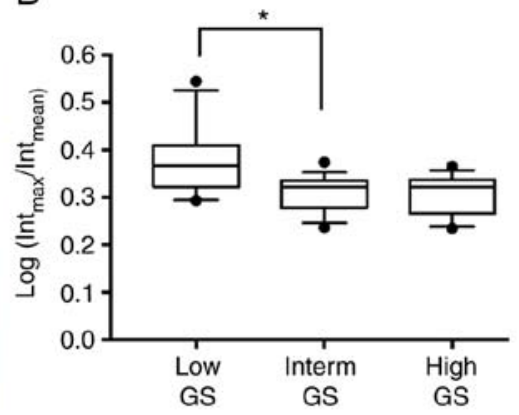

$\mathrm{D}$

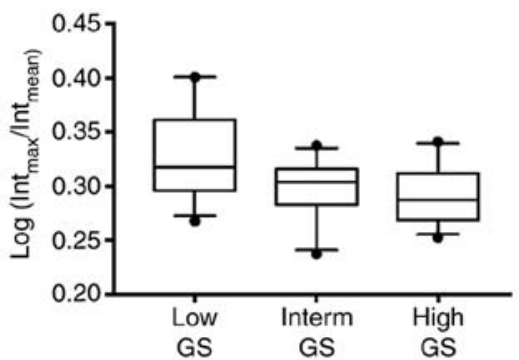

Figure 1. Expression levels of $\mathrm{ET}_{\mathrm{A}} \mathrm{R} / \mathrm{ET}_{\mathrm{B}} \mathrm{R}$ in TMAs from PCa samples. The images indicate the expression levels of ET $\mathrm{T}_{\mathrm{A}} \mathrm{R} / \mathrm{ET}_{\mathrm{B}} \mathrm{R}$ in $\mathrm{TMAs}_{\mathrm{A}}$ of $\mathrm{PCa}$ samples with low, intermediate, and high GS. (A) Immunohistochemistry analysis of $\mathrm{ET}_{\mathrm{A}} \mathrm{R}$. (B) Semi-quantification of the DAB signal. (C) Immunohistochemistry analysis of $\mathrm{ET}_{B} \mathrm{R}$. (D) Semi-quantification of the DAB signal. The box plots represent the signal intensity of $\mathrm{ET}_{\mathrm{A}} \mathrm{R}$ and $\mathrm{ET}_{\mathrm{B}} \mathrm{R}$ in each group. The points outside the box represent the outliers. Total number of samples analyzed, n=32; low GS $(<7), \mathrm{n}=7$; intermediate GS $(=7)$, n=14; and high GS ( $>7)$, n=11. The box plots show the mean \pm SD. ${ }^{*} \mathrm{P}<0.05$ (Kruskal-Wallis test/Dunn's multiple comparisons test). Scale bar, $100 \mu \mathrm{m}$. PCa, prostate cancer; GS, Gleason Score; ET $\mathrm{R}$, endothelin A receptor; $\mathrm{ET}_{\mathrm{B}} \mathrm{R}$, endothelin B receptor; ET-1, endothelin-1; TMA, tissue microarray; DAB, 3,3'-diaminobenzidine; Interm, intermediate.

analyzed was 32 for low GS $(<7), 14$ for intermediate GS $(=7)$ and 11 for high GS $(>7)$. The bar shows the mean \pm SD. $\mathrm{P} \leq 0.05$ was considered to indicate a statistically significant difference.

\section{Results}

Expression levels of $E T_{A} R$ and $E T_{B} R$ in TMAs of samples. In the present study, quantitative immunohistochemistry for $\mathrm{ET}_{\mathrm{A}} \mathrm{R}$ and $\mathrm{ET}_{\mathrm{B}} \mathrm{R}$ was performed on constructed TMAs. Intracellular staining of $\mathrm{ET}_{\mathrm{A}} \mathrm{R}$ and $\mathrm{ET}_{\mathrm{B}} \mathrm{R}$ was observed in PCa samples (Fig. 1A and C). Furthermore, semi-quantification analysis indicated that the intensity of $\mathrm{ET}_{\mathrm{A}} \mathrm{R}$ immunostaining was significantly higher in samples with low GS (Kruskal-Wallis test; $\mathrm{P}<0.05$ ) compared with in samples with intermediate GS (Fig. 1A and B). No changes in $\mathrm{ET}_{\mathrm{B}} \mathrm{R}$ were observed to be associated with GS in primary tumor samples (Fig. 1C and D). However, in benign prostatic hyperplasia samples, used as a non-neoplastic control, $\mathrm{ET}_{\mathrm{A}} \mathrm{R}$ was revealed to be located in epithelial and stromal cells (Fig. $\mathrm{S} 1 \mathrm{~A}$ ), and $\mathrm{ET}_{\mathrm{B}} \mathrm{R}$ was revealed to be primarily located in epithelial cells (Fig. S1B).

Expression levels of ET-1, ET $T_{A} R$ and $E T_{B} R$ in PCa cell lines. Basal expression levels of ET-1, $\mathrm{ET}_{\mathrm{A}} \mathrm{R}$ and $\mathrm{ET}_{\mathrm{B}} \mathrm{R}$ in $\mathrm{LNCaP}$ and PC3 cells were determined using RT-qPCR and western blotting. In addition, $\mathrm{ET}_{\mathrm{A}} \mathrm{R}$ and $\mathrm{ET}_{\mathrm{B}} \mathrm{R}$ levels were also determined by immunofluorescence. PC 3 cells were demonstrated to exhibit the highest levels of $\mathrm{ET}_{\mathrm{A}} \mathrm{R}$ and ET-1 expression at the mRNA $\left(\mathrm{ET}_{\mathrm{A}} \mathrm{R}\right.$; Mann-Whitney test; $\mathrm{P}=0.05$; Fig. $2 \mathrm{~A}$;
ET-1; Mann-Whitney test; $\mathrm{P}=0.05$; Fig. 3A) and protein levels $\left(\mathrm{ET}_{\mathrm{A}} \mathrm{R}\right.$; Mann-Whitney test; $\mathrm{P}<0.05$; Fig. 2B and E; ET-1 Mann-Whitney; $\mathrm{P}=0.05$; Fig. 3B). By contrast, LNCaP cells were revealed to express increased levels of $\mathrm{ET}_{\mathrm{B}} \mathrm{R}$ mRNA $\left(\mathrm{ET}_{\mathrm{B}} \mathrm{R}\right.$; Mann-Whitney test; $\mathrm{P}=0.05$; Fig. 2C) and protein $\left(\mathrm{ET}_{\mathrm{B}} \mathrm{R}\right.$; Mann-Whitney test; $\mathrm{P}=0.05$; Fig. $2 \mathrm{D}$ and $\left.\mathrm{F}\right)$ compared with PC3 cells. Negative controls are shown in Fig. 2G.

Intracellular $\mathrm{Ca}^{2+}$ measurement revealed that activity of $E T_{A} R$ is induced by ET-1 in PC3 cells. Since $\mathrm{ET}_{\mathrm{A}} \mathrm{R}$ is a Gq protein-coupled receptor $(15,17)$, the activity of this receptor was evaluated via intracellular calcium measurement. The results in Fig. 3C indicated that activation of $\mathrm{ET}_{\mathrm{A}} \mathrm{R}$ by ET-1 induced an intracellular $\mathrm{Ca}^{2+}$ transient signal, which was reflected as an increase in relative fluorescence intensity (F/F0) when adding ET-1 at $60 \mathrm{sec}$ compared with carbachol (positive control; Fig. 3D), suggesting the exit of calcium from the endoplasmic reticulum and/or the subsequent entry of calcium from the extracellular medium. This effect was inhibited by a selective antagonist for $\mathrm{ET}_{\mathrm{A}} \mathrm{R}, \mathrm{BQ123}$ (Fig. 3D), and the non-selective antagonist Bosentan (Fig. 3E).

Effect of ET-1 on the expression levels of steroidogenic pathway enzymes and AR in PC3 cells. In the present study, the effect of ET-1 on the enzymes of the steroidogenic pathway in PC3 cells was investigated. The effect was not determined in LNCaP cells since PC 3 cells expressed higher levels of ET-1 and $\mathrm{ET}_{\mathrm{A}} \mathrm{R}$. Therefore, by using PC3 cells, the effects could be observed more clearly. It was demonstrated 
A

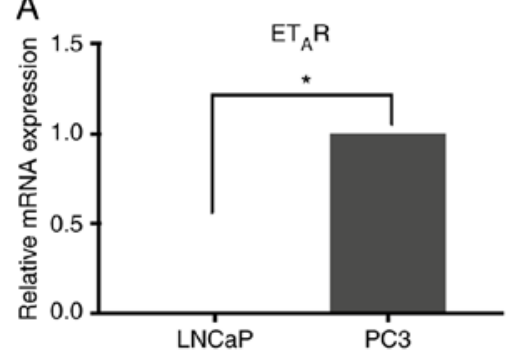

C

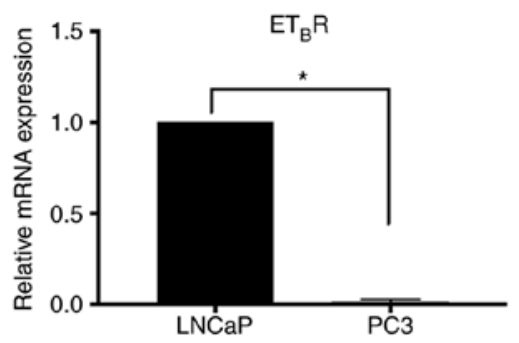

B

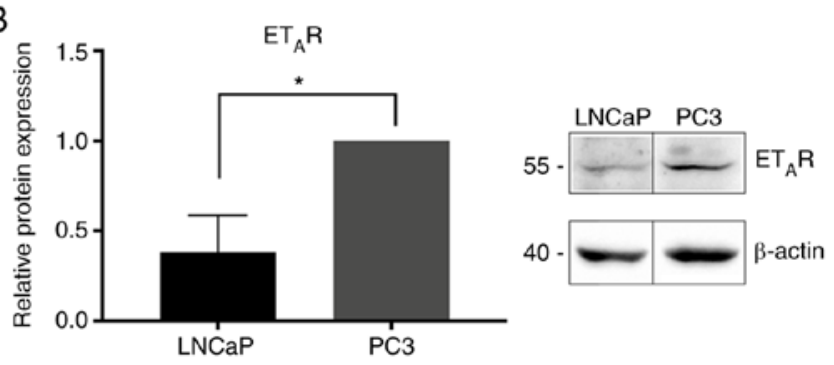

D

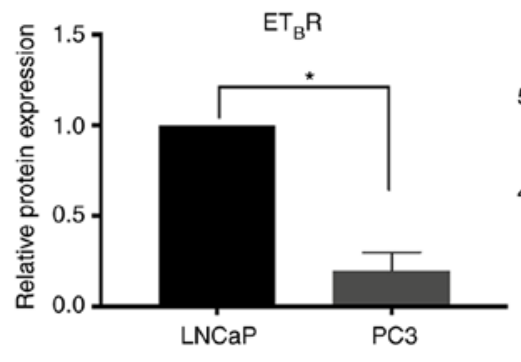

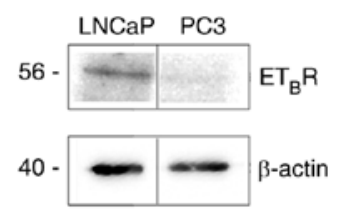

$\mathrm{F}$

ET ${ }_{B} R \quad$ DAPI MERGE

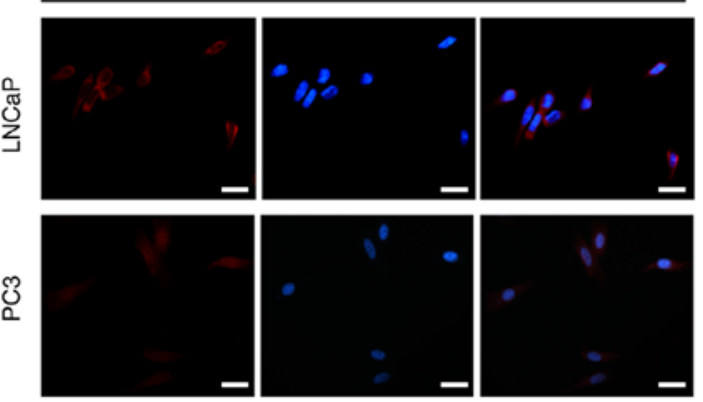

\section{E}
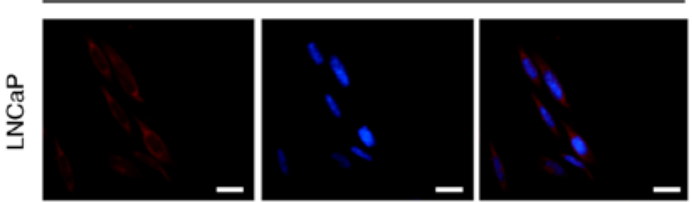

ญ్
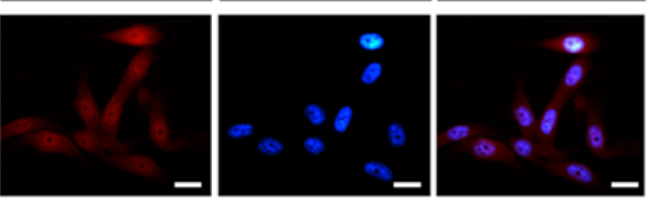

G

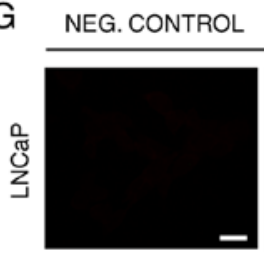

DAPI

MERGE
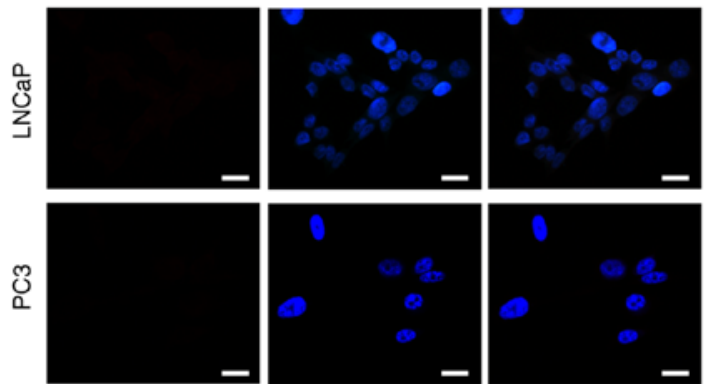

Figure 2. $\mathrm{ET}_{\mathrm{A}} \mathrm{R}$ and $\mathrm{ET}_{\mathrm{B}} \mathrm{R}$ expression in prostate cancer cells. (A) $\mathrm{ET}_{\mathrm{A}} \mathrm{R}$ mRNA expression normalized to Pumilio compared with PC3 cells. (B) ET $\mathrm{R}$ protein expression in PC3 and LNCaP cells. Quantification was normalized to $\beta$-actin and PC3 cells. (C) ET $\mathrm{B}_{\mathrm{B}} \mathrm{R}$ mNA expression normalized to Pumilio compared with LNCaP cells. (D) $\mathrm{ET}_{\mathrm{B}} \mathrm{R}$ protein expression in PC3 and LNCaP cells normalized to Pumilio compared with LNCaP cells. Immunofluorescence analysis of (E) $\mathrm{ET}_{\mathrm{A}} \mathrm{R}$ and $(\mathrm{F}) \mathrm{ET}_{\mathrm{B}} \mathrm{R}$ in PC3 and LNCaP cells. (G) Negative controls. Data are presented as the mean $\pm \mathrm{SD}$ ( $\mathrm{n}=3$ independent experiments) of arbitrary units. ${ }^{*} \mathrm{P}<0.05$ (Mann-Whitney test). Scale bar, $20 \mu \mathrm{m}$. The values 55, 56 and 40 correspond to mass units $(\mathrm{kDa}) . \mathrm{ET}_{\mathrm{A}} \mathrm{R}$, endothelin $\mathrm{A}$ receptor; ET ${ }_{\mathrm{B}} \mathrm{R}$, endothelin $\mathrm{B}$ receptor; Neg., negative.

that ET-1 treatment increased the expression levels of CyP11A1 (Kruskal-Wallis test; P<0.05; Fig. 4A and B-D), $3 \beta$ HSD2 (Kruskal-Wallis test; $\mathrm{P}<0.05$; Fig. 4A and $\mathrm{H}-\mathrm{J}$ ) and AR (Kruskal-Wallis test; $\mathrm{P}<0.05$; Fig. 5A-C) in $\mathrm{PC} 3$ cells compared with the control without ET-1. Blocking ET-1 receptors with BQ123 and/or Bosentan prevented the stimulatory effect of ET-1 on the expression of CyP11A1 (ET-1/BQ123 + ET-1; Kruskal-Wallis test; P<0.001; Fig. 4B), $3 \beta$ HSD2 (ET-1/Bosentan + ET-1; Kruskal-Wallis test; $\mathrm{P}<0.05$;
Fig. 4J) and AR (ET-1/BQ123 + ET-1; Kruskal-Wallis test; $\mathrm{P}<0.01$; Fig. 5B; ET-1/Bosentan + ET-1; Kruskal-Wallis test; $\mathrm{P}<0.05$; Fig. 5D). Additionally, blocking $\mathrm{ET}_{\mathrm{B}} \mathrm{R}$ with BQ788 decreased, with respect to ET-1, the expression levels of $3 \beta$ HSD2 (ET-1/BQ788 + ET-1; Kruskal-Wallis test; $\mathrm{P}<0.05$; Fig. 4I). There were no changes observed in CyP17A1 and aldo-keto reductase family member $\mathrm{C} 2$ (AKR1C2) protein expression in the three antagonist treatment groups, with respect to ET-1 (Fig. 4E-G and K-M). The aforementioned 

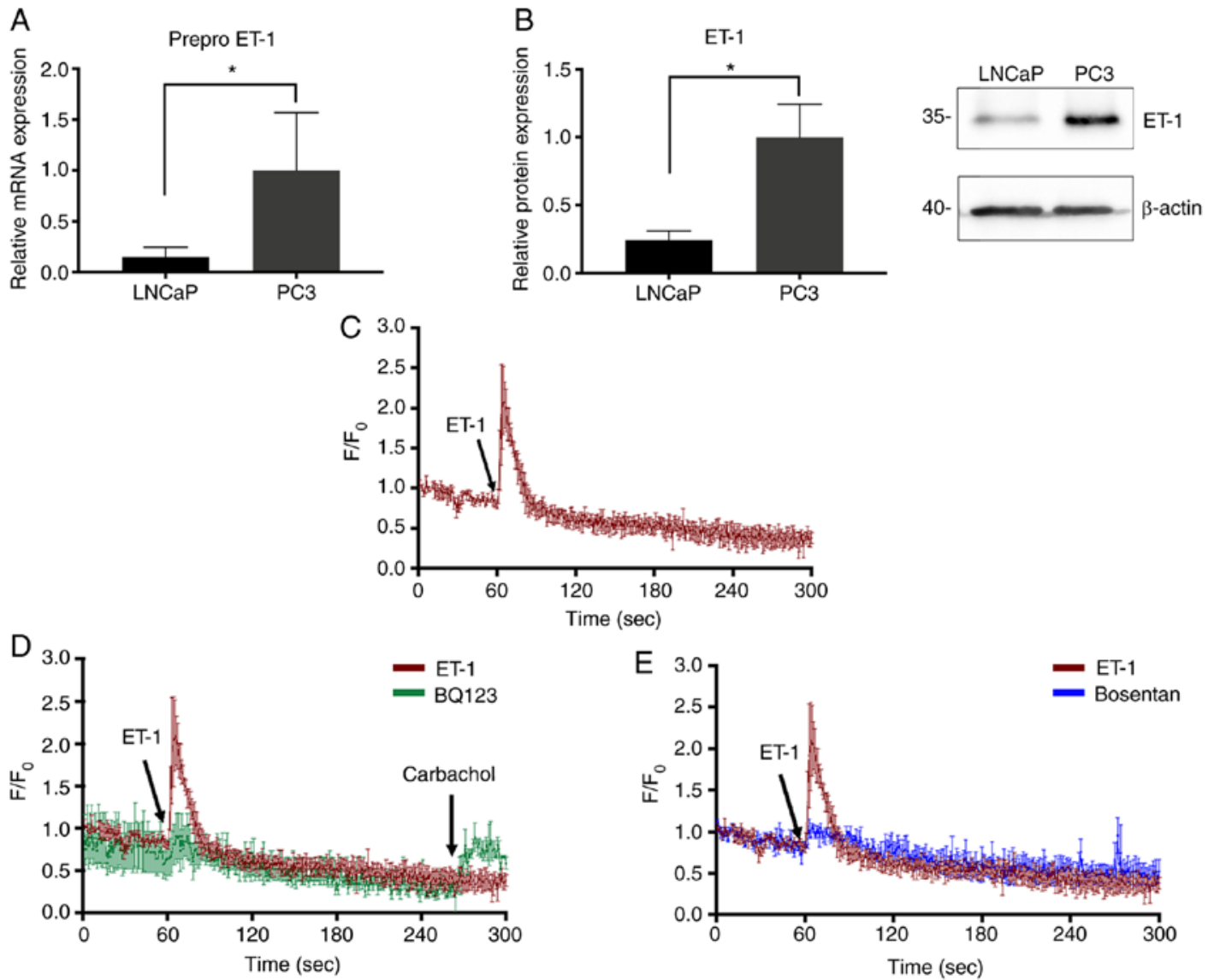

Figure 3. ET-1 expression and effect of ET-1 on calcium signaling in PCa cells. (A) Prepro-ET-1 mRNA expression normalized to Pumilio compared with PC3 cells. (B) ET-1 protein expression in PC3 and LNCaP cells. Quantification was normalized to $\beta$-actin and PC3 cells. (C) Addition of $100 \mathrm{nM}$ ET-1. (D) Cells were incubated with $1 \mu \mathrm{M} \mathrm{BQ} 123$ and stimulated with ET-1. After $240 \mathrm{sec}$, cells were stimulated with carbachol. (E) Cells were incubated with $1 \mu \mathrm{M}$ Bosentan and stimulated with ET-1. Data are presented as the mean $\pm \mathrm{SD}$ ( $\mathrm{n}=3$ independent experiments). ${ }^{*} \mathrm{P}<0.05$ (Mann-Whitney test). The values 35 and 40 correspond to mass units (kDa). F/ $\mathrm{F}_{0}$, relative fluorescence intensity; PCa, prostate cancer; ET-1, endothelin-1; BQ123, 2-[(3R,6R,9S,12R,15S)-6-(1H-indol-3-ylmethyl)-9(2-methylpropyl)-2,5,8,11,14-pentaoxo-12-propan-2-yl-1,4,7,10,13-pentazabicyclo[13.3.0]octadecan-3-yl] acetic acid.

results demonstrated that $\mathrm{ET}-1$ may regulate the protein expression levels of CyP11A1, $3 \beta$ HSD2 and AR via $\mathrm{ET}_{\mathrm{A}} \mathrm{R}$ or $\mathrm{ET}_{\mathrm{B}} \mathrm{R}$.

Effect of ET-1 on T secretion in PC3 cells. To determine if the increase in the expression levels of steroidogenic enzymes was associated with the steroidogenic process, $T$ production was evaluated in PC3 cells. Blocking of endothelin receptors was indicated to induce a decrease in T concentration (ET-1/BQ123 + ET-1; Kruskal-Wallis test; P<0.05; Fig. 5E; ET-1/BQ788 + ET-1; Kruskal-Wallis test; $\mathrm{P}<0.05$; Fig. $5 \mathrm{~F}$ ).

\section{Discussion}

ADT is the first-line treatment for patients with localized and advanced PCa (4). However, patients with PCa may develop resistance and this can lead to $\operatorname{CRPC}(8,9)$. Upregulation of the expression levels of androgen biosynthesis enzymes has been identified in tissues from patients with CRPC (9). Additionally, high plasma concentrations of ET-1 have been reported in patients with CRPC (13-17). It has been previously proposed that ET-1 may contribute to the transition from androgen-sensitive PCa to CRPC (24). However, to the best of our knowledge, the factors that may promote androgen resistance are yet to be determined. In 2009, Lee et al (20) demonstrated that ET-1 increases c-myc expression via $\mathrm{ET}_{\mathrm{A}} \mathrm{R}$, leading to increased AR expression in PCa cells within androgen-free medium. Furthermore, steroidogenic cell lines expressing endothelin receptor have been previously indicated to increase basal T secretion following ET-1 stimulation $(10,11)$.

The present study determined the expression levels of $\mathrm{ET}_{\mathrm{A}} \mathrm{R}$ and $\mathrm{ET}_{\mathrm{B}} \mathrm{R}$ in PCa TMAs, including in samples with different GSs $(<7,7$ and $>7)$. The results demonstrated that low GS samples exhibited higher $\mathrm{ET}_{\mathrm{A}} \mathrm{R}$ expression compared with intermediate GS samples, indicating that in primary tumors from patients without treatment, the expression levels of $\mathrm{ET}_{\mathrm{A}} \mathrm{R}$ were decreased and may be associated with the progression of PCa. Upregulation of $\mathrm{ET}_{\mathrm{A}} \mathrm{R}$ and ET-1 expression has been demonstrated in the early stages of $\mathrm{PCa}(16)$ and higher expression levels of $\mathrm{ET}_{\mathrm{A}} \mathrm{R}$ and $\mathrm{ET}-1$ are associated with advanced tumor stage (25). Furthermore, androgen-sensitive cells (LNCaP) cultured in androgen-deprived medium for 5 months have been indicated to exhibit increased levels of $\mathrm{ET}_{\mathrm{A}} \mathrm{R}$ and ET-1 mRNA, suggesting that this axis may serve an important role in the progression of PCa to CRPC (26). However, in the present study, no variation of $\mathrm{ET}_{\mathrm{B}} \mathrm{R}$ was observed in $\mathrm{PCa}$ samples with different GSs. Previous immunohistochemical 


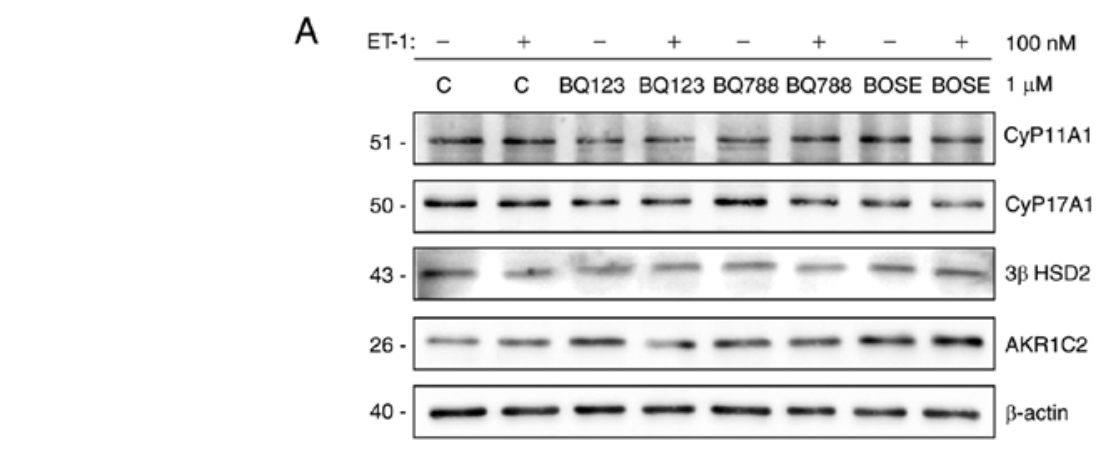

B
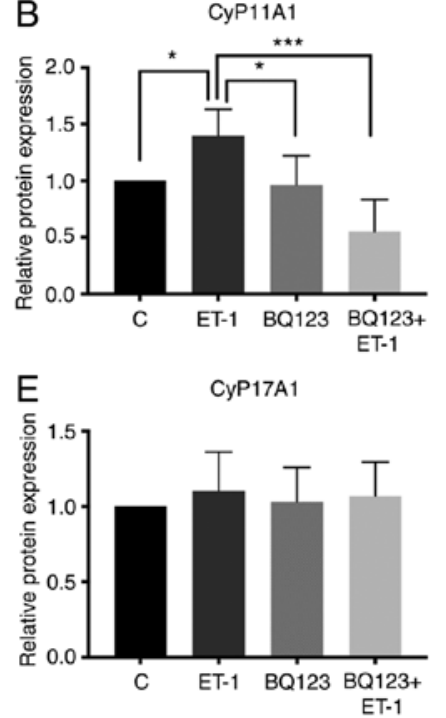

$\mathrm{H}$

$3 \beta \mathrm{HSD} 2$

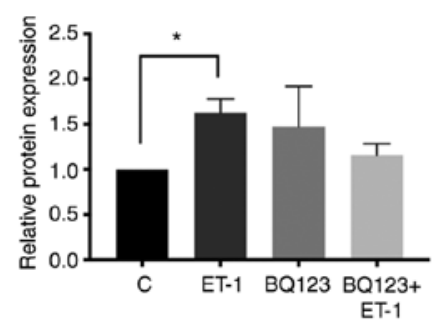

K

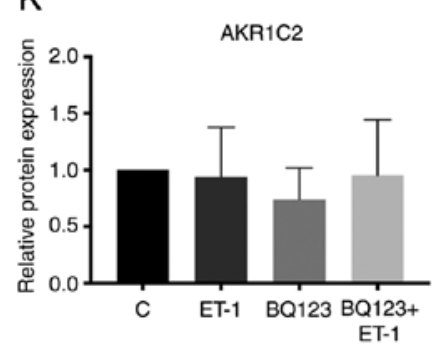

C

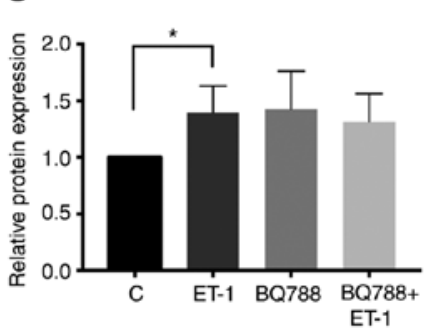

F

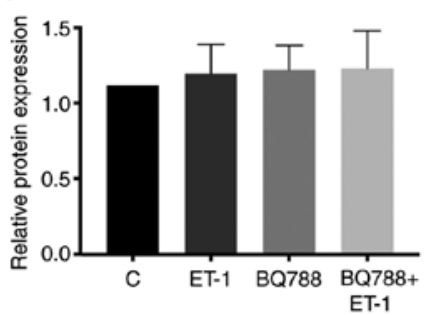

I

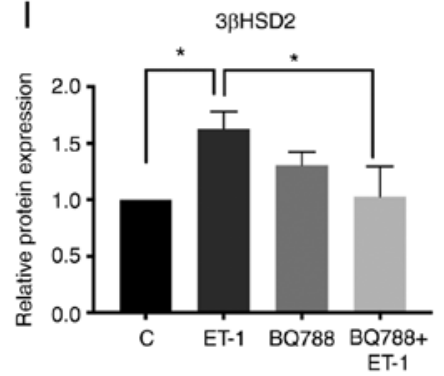

L

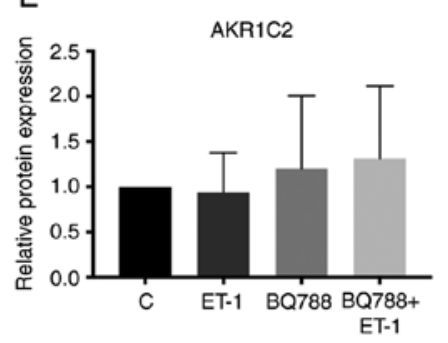

D

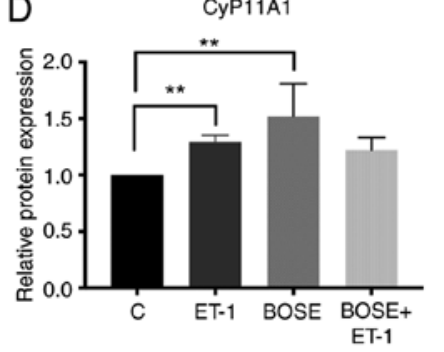

G

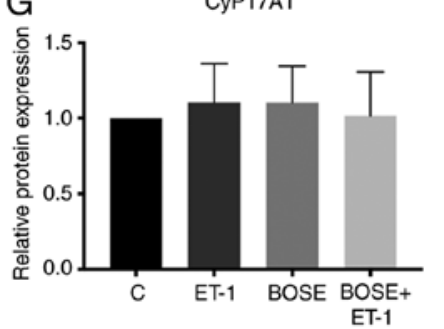

J

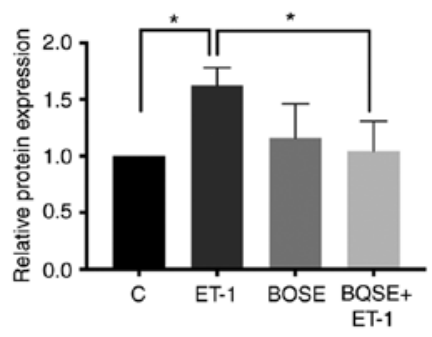

M

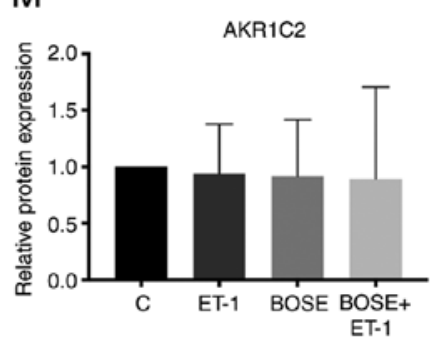

Figure 4. Effect of ET-1 on the expression levels of steroidogenic enzymes. (A) Lysed PC3 cells were analyzed by western blotting and membranes were incubated with antibodies against CyP11A1, CyP17A1, 3 $\beta$ HSD2, AKR1C2 and $\beta$-actin. (B) Protein expression levels of CyP11A1 in the presence or absence of BQ123. (C) Protein expression levels of CyP11A1 in the presence or absence of BQ788. (D) Protein expression levels of CyP11A1 in the presence or absence of BOSE. (E) Protein expression levels of CyP17A1 in the presence or absence of BQ123. (F) Protein expression levels of CyP17A1 in the presence or absence of BQ788. (G) Protein expression levels of CyP17A1 in the presence or absence of BOSE. (H) Protein expression levels of $3 \beta$ HSD2 in the presence or absence of BQ123. (I) Protein expression levels of 3 $\beta$ HSD2 in the presence or absence of BQ788. (J) Protein expression levels of 3 $\beta$ HSD2 in the presence or absence of BOSE. (K) Protein expression levels of AKR1C2 in the presence or absence of BQ123. (L) Protein expression levels of AKR1C2 in the presence or absence of BQ788. (M) Protein expression levels of AKR1C2 in the presence or absence of BOSE. Quantification was normalized to $\beta$-actin and control PC 3 cells. Data are presented as the mean $\pm \mathrm{SD}$ ( $\mathrm{n}=3$ independent experiments). ${ }^{*} \mathrm{P}<0.05,{ }^{* *} \mathrm{P}<0.01,{ }^{* * *} \mathrm{P}<0.001$ (Kruskal Wallis test/ Dunn's multiple comparisons test). The values 51, 50, 43, 26 and 40 correspond to mass units (kDa). ET-1, endothelin-1; BQ123, 2-[(3R,6R,9S,12R,15S)6-(1H-indol-3-ylmethyl)-9-(2-methylpropyl)-2,5,8,11,14-pentaoxo-12-propan-2-yl-1,4,7,10,13-pentazabicyclo[13.3.0]octadecan-3-yl] acetic acid; BQ788, 2,6-Dimethylpiperidinecarbonyl- $\gamma$-Methyl-Leu- $\mathrm{N}_{\text {in }}$-(Methoxycarbonyl)-D-Trp-D-Nle,-N-[N-[N-[(2,6-Dimethyl-1-piperidinyl)carbonyl]-4-methylL-leucyl]-1-(methoxycarbonyl)-D-tryptophyl]-D-norleucine sodium salt; BOSE, bosentan; CyP11A1, cytochrome P450 family 11 subfamily A member 1;

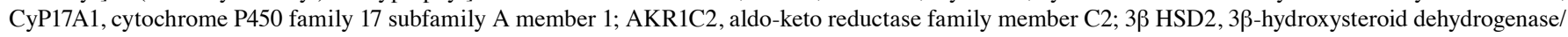
isomerase 2. 


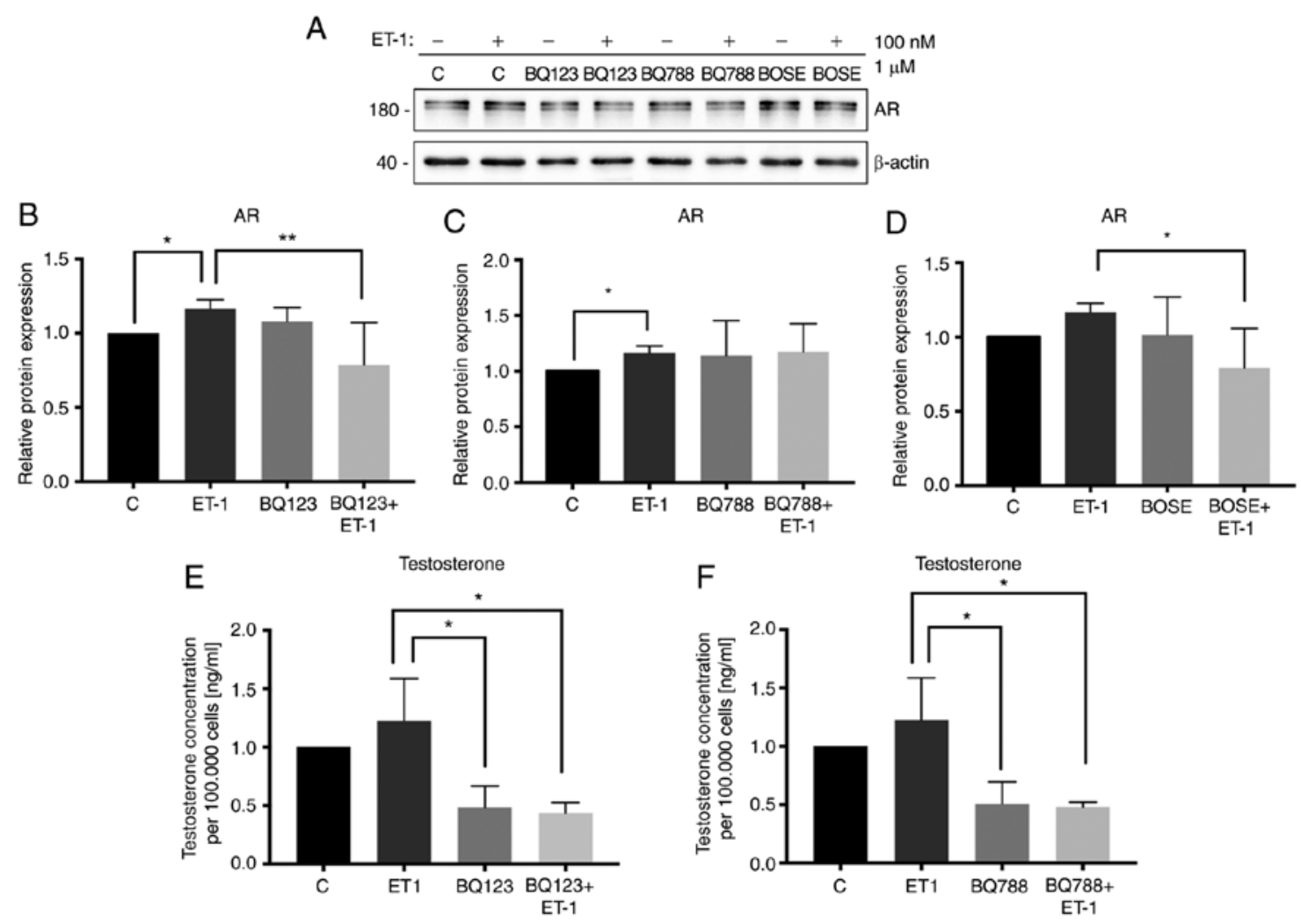

Figure 5.Effect of ET-1 on expression levels of AR and testosterone secretion.(A) Lysed PC3 cells were analyzed by western blotting and membranes were incubated with antibodies against AR and $\beta$-actin. (B) Protein expression levels of AR in the presence or absence of BQ123. (C) Protein expression levels of AR in the presence or absence of BQ788. (D) Protein expression levels of AR in the presence or absence of BOSE. Quantification was normalized to $\beta$-actin and control PC 3 cells. The cells were stimulated with $100 \mathrm{nM}$ ET-1 and previously incubated with BQ123 or BQ788 for $96 \mathrm{~h}$. (E) Testosterone secretion in presence or absence of BQ123. (F) Testosterone secretion in presence or absence of BQ788. Data are presented as the mean $\pm \mathrm{SD}$ ( $\mathrm{n}=3$ independent experiments). ${ }^{*} \mathrm{P}<0.05$, ${ }^{* *} \mathrm{P}<0.01$ (Kruskal Wallis test/Dunn's multiple comparisons test). Quantification was normalized to control PC3 cells. The values 180 and 40 correspond to mass units (kDa). ET-1, endothelin-1; BQ123, 2-[(3R,6R,9S,12R,15S)-6-(1H-indol-3-ylmethyl)-9-(2-methylpropyl)-2,5,8,11,14-pentaoxo-12-propan-2-yl-1,4,7,10,13-pentazabicyclo[13.3.0] octadecan-3-yl] acetic acid; BQ788, 2,6-Dimethylpiperidinecarbonyl- $\gamma$-Methyl-Leu- $\mathrm{N}_{\text {in }}$-(Methoxycarbonyl)-D-Trp-D-Nle,-N-[N-[N-[(2,6-Dimethyl-1piperidinyl)carbonyl]-4-methyl-L-leucyl]-1-(methoxycarbonyl)-D-tryptophyl]-D-norleucine sodium salt; BOSE, bosentan; AR, androgen receptor.

studies of prostate adenocarcinoma tissue have revealed the decreased expression of $\mathrm{ET}_{\mathrm{B}} \mathrm{R}$ compared with $\mathrm{ET}_{\mathrm{A}} \mathrm{R}$ levels $(27,28)$.

In the present study, the expression levels of $\mathrm{ET}_{\mathrm{A}} \mathrm{R}, \mathrm{ET}_{\mathrm{B}} \mathrm{R}$ and ET-1 were also measured in PCa cell lines, indicating that the androgen-insensitive cell line PC3 expressed the highest mRNA and protein levels of $\mathrm{ET}_{\mathrm{A}} \mathrm{R}$ and ET-1. LNCaP cells expressed higher levels of $\mathrm{ET}_{\mathrm{B}} \mathrm{R}$ compared with PC3 cells. $\mathrm{ET}_{\mathrm{B}} \mathrm{R}$ is a receptor, which is mainly expressed in prostatic epithelial cells and is associated with the regulation of extracellular ET-1 via lysosomal degradation (29). The present study indicated that androgen-sensitive LNCaP cells expressed lower levels of ET-1 but higher levels of ET $_{B}$ R compared with PC3 cells, which was in agreement with previous studies $(17,30)$. These results suggested that the ET-1 axis may serve a role in $\mathrm{PCa}$ progression and may contribute to the development of androgen resistance.

The activity of ETs is mediated by the activation of $\mathrm{ET}_{\mathrm{A}} \mathrm{R}$ and $\mathrm{ET}_{\mathrm{B}} \mathrm{R}$, which are $\mathrm{Gq}$ protein-coupled receptors $(15,17)$. Therefore, the present study revealed an expected increase in intracellular calcium in ET-1-stimulated PC 3 cells. Accordingly, this effect was suppressed by preincubating the cells with endothelin receptor antagonists (BQ123 and Bosentan).

The ET-1 signaling pathway may be associated with the transition to an androgen-insensitive stage in patients with
PCa (24). This can be hypothesized as an increase in AR expression in LNCaP cells after 3 months of androgen deprivation has been previously reported (20). However, the effect of ET-1 on steroidogenesis in non-steroidogenic cells, such as PCa cells, is yet to be determined. Therefore, the basal expression of steroidogenic pathway enzymes in PCa cell lines was examined in the present study.

Steroidogenesis is a physiological process, which mainly occurs in the adrenal glands and gonads $(31,32)$, and different enzymes, including CyP11A1, CyP17A1, $3 \beta$ HSD2, $17 \beta$-hydroxysteroid dehydrogenase type 3 and steroid 5 $\alpha$-reductase 1 , are involved in $\mathrm{T}$ production. Steroidogenesis can be acute or chronically regulated depending on the tissue type, and both types of regulation are controlled by different factors or hormones $(31,33)$. An increase in the expression levels of enzymes that are involved in the synthesis of androgens, including CyP11A1, CyP17A1 and $3 \beta$ HSD1, has been demonstrated in samples from patients with advanced PCa $(9,34,35)$. Therefore, the effect of ET-1 on CyP11A1, CyP17A1, AKR1C2, $3 \beta$ HSD2 and AR was evaluated in the present study. The results indicated that $\mathrm{CyP} 11 \mathrm{~A} 1,3 \beta \mathrm{HSD} 2$ and $\mathrm{AR}$ protein expression increased with ET-1 treatment and this effect was attenuated by a selective (BQ123) and non-selective antagonist (Bosentan) of the endothelin receptor. Other enzymes of the steroidogenic pathway could be tested, and this point could 
be considered a limitation of the present study. However, the enzymes evaluated in the present study are those showing significant expression changes in tissues of patients with CRPC (9). In addition, endothelin receptor blockade induces a decrease of $\mathrm{T}$ concentration in the culture medium of PC3 cells. In 2006, Alimirah et al (36), reported that both PC3 and DU145 cells effectively express AR. Their study revealed that this receptor does not have the same characteristics of normal AR and, depending on the antibodies used, which bind to different regions of $\mathrm{AR}$, it is possible to find double bands in these cell lines (36). Some of the results regarding the levels of the AR and T may be reproduced in DU145 cells (PCa cells from brain metastasis), since they express $\mathrm{ET}_{\mathrm{A}} \mathrm{R}$ (data not shown) and AR and produce T (37). To the best of our knowledge, the aforementioned results are the first to indicate that ET-1 regulates steroidogenesis via $\mathrm{ET}_{\mathrm{A}} \mathrm{R}$ or $\mathrm{ET}_{\mathrm{B}} \mathrm{R}$ in PC3 cells. On the other hand, there are cell lines derived from vertebral (VCaP) and lymphonodular (LAPC4) metastases of patients with PCa refractory to hormone therapy; however, these cell lines exhibit high levels of AR and androgen sensitivity (38). The objective of the present study was to analyze the effect of ET-1 in an androgen-insensitive cell line (PC3), in which high expression levels of $\mathrm{ET}_{\mathrm{A}} \mathrm{R}$ were observed.

The results of the present study indicated that ET-1 may serve an important role in the production of $\mathrm{T}$ in PCa cells via the canonical pathway as the main pathway for $\mathrm{T}$ synthesis in $\mathrm{PCa}$. Changes in the protein expression levels of steroidogenic enzymes may be induced by ET-1 or $\mathrm{ET}_{\mathrm{A}} \mathrm{R}$ via two potential mechanisms: A cyclic AMP (cAMP)/protein kinase A (PKA)-dependent signaling pathway or a cAMP-independent signaling pathway with protein kinase $\mathrm{C}$ involvement. These signaling pathways may allow phosphorylation of transcriptional factors (steroidogenic factor 1, GATA binding protein 4 or CAMP responsive element binding protein), which are associated with the transcription of encoding genes for steroidogenic enzymes $(31,39,40)$. However, cAMP/PKA signaling has been indicated to be the main regulatory mechanism for steroidogenesis, since the cAMP-independent pathways are usually associated with the modulation or enhancement of the biosynthetic process, acting synergistically with PKA $(31,33)$.

These findings suggested that ET-1, via the activation of its receptors, may be actively associated with $\mathrm{T}$ production in $\mathrm{PCa}$. This mechanism may contribute to the progression of PCa to CRPC, which indicated that ET-1 and its receptors may be potential therapeutic targets that can be used in the treatment of advanced PCa.

\section{Acknowledgements}

The authors would like to thank Ms. Graciela Caroca (Department of Basic and Clinical Oncology, Faculty of Medicine, University of Chile, Santiago 8380453, Chile) for their excellent technical assistance.

\section{Funding}

The present study was supported by the following grants: FONDECYT grant nos. 1151214, 1140417, 1201704, 1160889 and 1190406. URedes grant no. URC-007/17, University of Chile grant nos. ENL22/19 and ENL23/19, and scholarships from the National Research and Development Agency (ANID) 21160703 and 21160886.

\section{Availability of data and materials}

The datasets used and/or analyzed during the current study are available from the corresponding author on reasonable request.

\section{Authors' contributions}

MJT performed the experimental design, experiments and statistical analysis, and wrote the manuscript. FLM participated in the design of testosterone measurement and drafted the manuscript. DH helped with the experimental design and writing of the manuscript. SI designed and helped in the immunohistochemical assays. AL assisted in the performance of some reverse transcription-quantitative PCR experiments of enzymes of the steroidogenic pathway. PL participated in intracellular calcium measurement design. EAC participated in the experimental design and helped to draft the manuscript. JT helped with the experimental design. HRC designed the general study and assisted in the writing of the manuscript. HRC and EAC confirm the authenticity of all the raw data. All authors read and approved the final manuscript.

\section{Ethics approval and consent to participate}

All protocols for tissue collection, use and processing have been approved by the institutional Ethical Committee of Faculty of Medicine, University of Chile (approvals nos. 135-2015 and 083-2020; Authorization for biopsy archive use of the Department of Pathology, University of Chile, 03012016, Santiago, Chile).

\section{Patient consent for publication}

Not applicable.

\section{Competing interests}

The authors declare that they have no competing interests.

\section{References}

1. Bray F, Ferlay J, Soerjomataram I, Siegel RL, Torre LA and Jemal A: Global cancer statistics 2018: GLOBOCAN estimates of incidence and mortality worldwide for 36 cancers in 185 countries. CA Cancer J Clin 68: 394-424, 2018.

2. Shah RB and Zhou M: Recent advances in prostate cancer pathology: Gleason grading and beyond. Pathol Int 66: 260-272, 2016.

3. Shariat SF and Roehrborn CG: Using biopsy to detect prostate cancer. Rev Urol 10: 262-280, 2008.

4. Perlmutter MD and Lepor M: Androgen deprivation therapy in the treatment of advanced prostate cancer. Rev Urol 9 (Suppl 1): S3-S8, 2007.

5. Kaarbø M, Klokk TI and Saatcioglu F: Androgen signaling and its interactions with other signaling pathways in prostate cancer. Bioessays 29: 1227-1238, 2007.

6. Anantharaman A and Friedlander TW: Targeting the androgen receptor in metastatic castrate-resistant prostate cancer: A review. Urol Oncol 34: 356-367, 2016.

7. Lonergan PE and Tindall DJ: Androgen receptor signaling in prostate cancer development and progression. J Carcinog 10: 20, 2011. 
8. Shore ND, Abrahamsson PA, Anderson J, Crawford ED and Lange P: New considerations for ADT in advanced prostate cancer and the emerging role of $\mathrm{GnRH}$ antagonists. Prostate Cancer Prostatic Dis 16: 7-15, 2012.

9. Armandari I, Hamid AR, Verhaegh G and Schalken J: Intratumoral steroidogenesis in castration-resistant prostate cancer : A target for therapy. Prostate Int 2: 105-113, 2014.

10. Conte D, Questino P, Fillo S, Nordio M, Isidori A and Romanelli F: Endothelin stimulates testosterone secretion by rat leydig cells. J Endocrinol 136: R1-R4, 1993.

11. Stojilkovic SS: Endothelin receptors and gonadal function: An invited commentary. Eur J Endocrinol 135: 391-393, 1996.

12. Ergün S, Harneit S, Paust HJ, Mukhopadhyay AK and Holstein AF: Endothelin and endothelin receptors A and B in the human testis. Anat Embryol (Berl) 199: 207-214, 1999.

13. Kopetz ES, Nelson JB and Carducci MA: Endothelin-1 as a target for therapeutic intervention in prostate cancer. Invest New Drugs 20: 173-182, 2002

14. Grant K, Loizidou M and Taylor I: Endothelin-1: A multifunctional molecule in cancer. Br J Cancer 88: 163-166, 2003.

15. Zonnenberg BA and Voest EE: The role of endothelin in hormone-refractory prostate cancer. Eur Urol (Suppl 2): 9-14, 2003.

16. Montironi R, Mazzucchelli R, Barbisan F, Stramazzotti D, Santinelli A, Lòpez Beltran A, Cheng L, Montorsi F and Scarpelli M: Immunohistochemical expression of Endothelin-1 and Endothelin-A and Endothelin-B receptors in high-grade prostatic intraepithelial neoplasia and prostate cancer. Eur Urol 52: 1682-1690, 2007

17. Niko B: Involvement of ion channels in Endothelin-1-induced signalling in human prostate cancer cells. J Clin Toxicol 02: 1-13, 2012

18. Russell FD and Davenport AP: Secretory pathways in endothelin synthesis. Br J Pharmacol 126: 391-398, 1999.

19. Barton $M$ and Yanagisawa $M$ : Endothelin: 20 years from discovery to therapy. Can J Physiol Pharmacol 86: 485-498, 2008

20. Lee JG, Zheng R, McCafferty-Cepero JM, Burnstein KL, Nanus DM and Shen R: Endothelin-1 enhances the expression of the androgen receptor via activation of the c-myc pathway in prostate cancer cells. Mol Carcinog 48: 141-149, 2009.

21. Gleason DF: Histologic grading of prostate cancer: A perspective. Hum Pathol 23: 273-279, 1992

22. Baidoo $\mathrm{E}$ and Kontoh $\mathrm{AK}$ : Implementation of gray level image transformation techniques. Int J Mod Educ Comput Sci 10: 44-53, 2018.

23. Livak KJ and Schmittgen TD: Analysis of relative gene expression data using real-time quantitative PCR and the 2(-Delta Delta C(T)) method. Methods 25: 402-408, 2001.

24. Whyteside AR, Hinsley EE, Lambert LA, McDermott PJ and Turner AJ: ECE-1 influences prostate cancer cell invasion via ET-1-mediated FAK phosphorylation and ET-1-independent mechanisms. Can J Physiol Pharmacol 88: 850-854, 2010.

25. Papanikolaou S, Bravou V, Papadaki H and Gyftopoulos K: The role of the endothelin axis in promoting epithelial to mesenchymal transition and lymph node metastasis in prostate adenocarcinoma. Urol Ann 9: 372-379, 2017.

26. D'Antonio JM, Ma C, Monzon FA and Pflug BR: Longitudinal analysis of androgen deprivation of prostate cancer cells identifies pathways to androgen independence. Prostate 68: 698-714 2008 .
27. Godara G, Pecher S, Jukic DM, D'Antonio JM, Akhavan A, Nelson JB and Pflug BR: Distinct patterns of endothelin axis expression in primary prostate cancer. Urology 70: 209-215, 2007.

28. Gohji K, Kitazawa S, Tamada H, Katsuoka Y and Nakajima M: Expression of endothelin receptor a associated with prostate cancer progression. J Urol 165: 1033-1036, 2001.

29. Nelson JB and Carducci MA: The role of endothelin-1 and endothelin receptor antagonists in prostate cancer. BJU Int 85 (Suppl 2): S45-S48, 2000.

30. Liu J and Liu X: Knockdown of ET-1 gene can inhibit the proliferation, invasion of human prostate cancer cell. Biomed Res 28: 3377-3382, 2017.

31. Miller WL: Steroidogenic enzymes. Endocr Dev 13: 1-18, 2008.

32. Yazawa T, Imamichi Y, Sekiguchi T, Miyamoto K, Uwada J, Khan MRI, Suzuki N,Umezawa A and Taniguchi T: Transcriptional regulation of ovarian steroidogenic genes: Recent findings obtained from stem cell-derived steroidogenic cells. Biomed Res Int 2019: 8973076, 2019.

33. Stocco DM, Wang XJ, Jo Y and Manna PR: Multiple signaling pathways regulating steroidogenesis and steroidogenic acute regulatory protein expression: More complicated than we thought. Mol Endocrinol 19: 2647-2659, 2005.

34. Bennett NC, Hooper JD, Lambie D, Lee CS, Yang T, Vesey DA, Samaratunga H, Johnson DW and Gobe GC: Evidence for steroidogenic potential in human prostate cell lines and tissues. Am J Pathol 181: 1078-1087, 2012.

35. Mostaghel EA, Solomon KR, Pelton K, Freeman MR and Montgomery RB: Impact of circulating cholesterol levels on growth and intratumoral androgen concentration of prostate tumors. PLoS One 7: e30062, 2012.

36. Alimirah F, Chen J, Basrawala Z, Xin H and Choubey D: DU-145 and PC-3 human prostate cancer cell lines express androgen receptor: Implications for the androgen receptor functions and regulation. FEBS Lett 580: 2294-2300, 2006.

37. Herrera D, Orellana-Serradell O, Villar P, Torres MJ, Paciucci R, Castellón EA and Contreras HR: Silencing of the transcriptional factor ZEB1 alters the steroidogenic pathway, and increases the concentration of testosterone and DHT in DU145 cells. Oncol Rep 41: 1275-1283, 2019.

38. van Bokhoven A, Varella-Garcia M, Korch C, Johannes WU, Smith EE, Miller HL, Nordeen SK, Miller GJ and Lucia MS: Molecular characterization of human prostate carcinoma cell lines. Prostate 57: 205-225, 2003.

39. Ruggiero $\mathrm{C}$ and Lalli E: Impact of ACTH signaling on transcriptional regulation of steroidogenic genes. Front Endocrinol (Lausanne) 7: 24, 2016

40. Bremer AA and Miller WL: Regulation of steroidogenesis. Cell Endocrinol Heal Dis 207-227, 2014.

This work is licensed under a Creative Commons Attribution-NonCommercial-NoDerivatives 4.0 International (CC BY-NC-ND 4.0) License. 